\title{
Does Parkinson's disease start in the gut?
}

\section{A doença de Parkinson começa no intestino?}

\author{
Oscar S. Gershanik
}

\begin{abstract}
Current understanding of the pathophysiology of Parkinson's disease suggests a key role of the accumulation of alpha-synuclein in the pathogenesis. This critical review highlights major landmarks, hypotheses and controversies about the origin and progression of synucleinopathy in Parkinson's disease, leading to an updated review of evidence suggesting the enteric nervous system might be the starting point for the whole process. Although accumulating and compelling evidence favors this theory, the remaining knowledge gaps are important points for future studies.
\end{abstract}

Keywords: Parkinson's disease; enteric nervous system; alpha-synuclein.

\section{RESUMO}

O atual entendimento sobre a fisiopatologia da doença de Parkinson (DP) sugere um papel central do acúmulo de alfa-sinucleína na patogenia da DP. Esta revisão crítica revisita marcos, teorias e controvérsias a respeito da origem e progressão da sinucleinopatia, apresentando uma atualização das principais evidências sugerindo que o sistema nervoso entérico seria o local inicial deste processo. Apesar das evidências a favor desta teoria serem crescentes e instigantes, as lacunas de conhecimento a este respeito são importantes pontos para estudos futuros.

Palavras-chave: doença de Parkinson; sistema nervoso entérico; alfa-sinucleína.

In 1997, two major discoveries contributed to the understanding of the pathogenesis of Parkinson's disease (PD). Firstly, the identification of mutations in the alpha-synuclein gene (SNCA) as being responsible for hereditary forms of $\mathrm{PD}^{1}$ and, secondly, the finding that aggregated, misfolded alphasynuclein (ASN) was one of the major components of Lewy bodies and Lewy neurites ${ }^{2}$, the hallmark lesions of sporadic forms of the disease. Other monogenic forms of the disease (LRRK2, and SNCA duplications and triplications) also have ASN deposits as a distinguishing pathological feature ${ }^{3}$. Other parkinsonian syndromes (multiple system atrophy and dementia with Lewy bodies) were found to be part of a spectrum of disorders, sharing the accumulation of misfolded ASN at the neuronal and glial level, giving birth to the concept of synucleinopathies: neurodegenerative diseases whose pathological marker is the presence of these deposits of abnormally conformed $\mathrm{ASN}^{4}$.

A significant body of evidence has accumulated in the last 20 years, pointing to a central role of ASN in the pathogenesis of PD. Alpha-synuclein, as mentioned above, is the major component of the pathological hallmark lesions of PD (Lewy bodies and Lewy neurites) ${ }^{2}$; point mutations in the
SNCA cause familial forms of $\mathrm{PD}^{1}$; increased levels of ASN (gene dose effect caused by duplications and triplications of the SNCA) can cause familial forms of PD in which the amount of coded protein correlates with the severity of disease $^{5}$; specific SNCA variants or polymorphisms confer the risk of developing idiopathic $\mathrm{PD}^{6}$; overexpression of human ASN in experimental animals recapitulates the key features of $\mathrm{PD}^{7}$; pathologic accumulation of ASN is toxic and can interfere with normal synaptic function, dopamine transport, and protein degradation ${ }^{8}$. Moreover, a widespread distribution of ASN pathology, at both the central and peripheral levels, reflects the expression of symptoms of $\mathrm{PD}$, establishing that the disease is a multisystem disorder with both motor and non-motor symptomatology 9 .

Another pivotal contribution to our understanding of the pathogenesis of PD has been the comprehensive and detailed description by Braak et al. ${ }^{10}$ of the spreading of ASN pathology in the brain of affected individuals. According to their findings, these authors established a pattern of disease progression that correlated with brain ASN pathology in which the course of the disease evolved in stages (I through VI) of increasing involvement. In stages I and II, the areas of

${ }^{1}$ Instituto de Neurociencias, Hospital Universitario Fundacion Favaloro, Laboratorio de Parkinson Experimental, ININFA-UBA-CONICET, Ciudad Autónoma de Buenos Aires, Argentina.

Correspondence: Oscar S. Gershanik; Solis 461, Ciudad Autonoma de Buenos Aires; E-mail: gersha@gmail.com

Conflict of interest: There is no conflict of interest to declare.

Received 25 September 2017; Received in final form 22 October 2017; Accepted 02 November 2017. 
the brain initially affected, the olfactory bulb and the dorsal motor nucleus of the vagus nerve (DMNV) correlate with the early presence of autonomic disturbances (constipation) and olfactory loss. Ascending pathology in stages III and IV, involving the locus coeruleus and substantia nigra, correlates with the development of sleep disorders and the initial appearance of motor symptomatology. Further spreading of the pathology to subcortical and cortical structures, characteristic of stages V and VI, heralds the development of cognitive and psychiatric disturbances. Although a significant number of cases fit this staged progression of the disease, according to Braak's hypothesis, some exceptions have been reported. Postmortem studies show that between $6.3 \%$ and $43 \%$ of cases do not follow the proposed caudo-rostral progression pattern of ASN pathology ${ }^{11}$. In $7 \%$ to $8.3 \%$ of clinically-manifest PD cases, with ASN inclusions in the midbrain and cortex corresponding to Lewy body stages IV-V, the medullary nuclei were spared, whereas mild parkinsonian symptoms had already been observed in stages II and III ${ }^{11}$.

Another controversial issue surrounding this hypothesis revolves around the potential pathogenic role of ASN. Evidence, based on experimental findings, suggests that soluble oligomeric /protofibrillar aggregates are the most neurotoxic forms of $\mathrm{ASN}^{12}$. These species, as well as the ready-formed fibrils, may also potentiate pathology by acting as seeds for the formation of additional aggregates ${ }^{13}$. Many intra- and extracellular targets have been singled out as potential sites for toxicity by these forms of ASN. They could interfere with pore formation at the cell membrane level leading to loss of ion homeostasis; cause impairment of protein degradation by the ubiquitin-proteasome system and the autophagy-lysosomal pathway; and compromise cellular respiration through impairment of the mitochondrial machinery. ${ }^{8}$. At the peripheral level, it is proposed that pathologic ASN aggregates may cause impairment of synaptic transmission and disturbance of axonal function leading to the demise of the neuron through a process similar to a "dying-back" neuropathy ${ }^{8}$. In support of the synaptotoxic effects of oligomeric forms of ASN, experimental evidence shows that incubation of brain tissue slices with recombinant ASN oligomers impairs long-term potentiation ${ }^{14}$.

Another issue subject to debate is related to the spreading of ASN pathology from cell to cell through a "prion-like" mechanism. The first such evidence originated in the postmortem finding of ASN pathology in implanted fetal grafts, after a prolonged incubation period, in the brains of PD patients receiving these implants ${ }^{13}$. This finding prompted a number of experiments trying to support this hypothesis. Injections of pathologic ASN or preformed ASN fibrils into the brains of transgenic and nontransgenic mice were able to initiate a rapidly-progressive PD-like neurodegenerative $\alpha$-synucleinopathy ${ }^{15,16}$. Likewise, injection of synthetic ASN fibrils into the brains of non-transgenic primates induced
PD-like ASN pathology within only three months after injection $^{17}$. Moreover, Lewy body extracts from PD brains were able to trigger ASN pathology and neurodegeneration in mice and monkeys ${ }^{18}$. Using A30P ASN mice, researchers were able to prove that the degree of pathological involvement and the corresponding development of motor impairment was tightly correlated with the levels of ASN oligomers ${ }^{19}$. In all cases, not only was there evidence of ASN induced pathology, but the pathological process spread throughout the brain.

Additional evidence supporting the hypothesis of ASNinduced toxicity came from experiments using a different approach. In these experiments, the intraperitoneal administration of monoclonal antibodies specific for misfolded ASN into non-transgenic mice, injected intrastriatally with preformed ASN fibrils, was able to reduce Lewy body/Lewy neurite pathology, ameliorate substantia nigra dopaminergic neuron loss, and improve motor impairments ${ }^{20}$.

Based on all the evidence presented in the preceding paragraphs, a pathogenic hypothesis has emerged in the last few years. Accumulation of ASN in the DMNV, considered to be the first vulnerable region of the central nervous system to become affected in PD, may actually originate in the enteric nervous system (ENS), where vagal fibers synapse with parasympathetic ganglionic neurons. A putative pathogen capable of passing through the mucosal lining of the gastrointestinal tract might induce ASN misfolding in the terminal axons of postganglionic enteric neurons followed by retrograde transport to the cholinergic preganglionic neurons of the DMNV, and from there spread in a caudo-rostral direction, involving other brain structures, as proposed by Braak et al. ${ }^{10,21}$ (Figure 1).

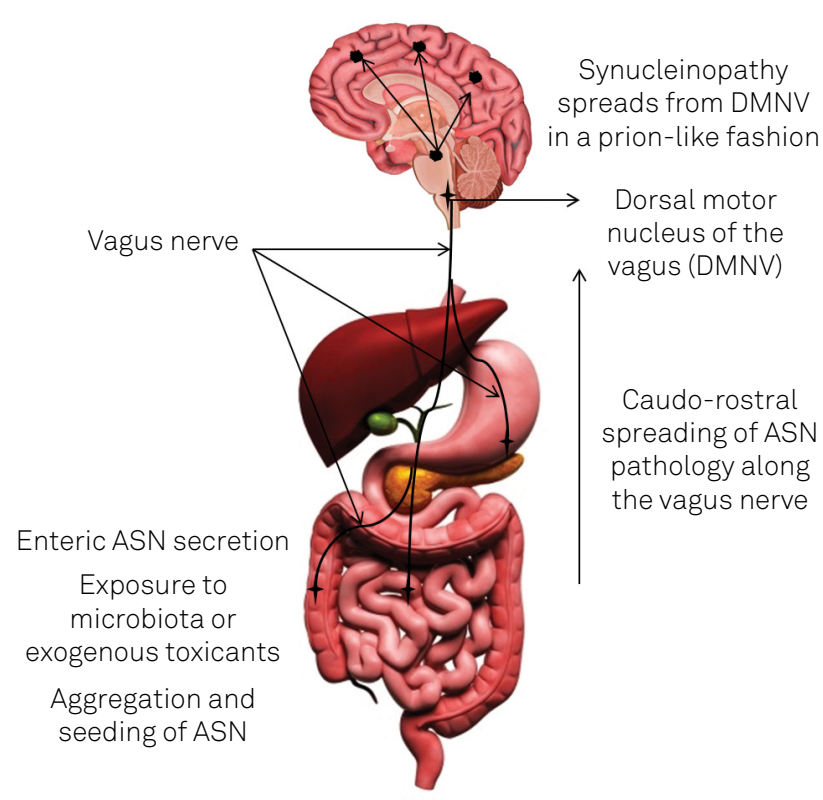

ASN: alpha-synuclein, DMNV: dorsal motor nucleus of the vagus. Figure 1. Proposed pathway of spreading of ASN pathology from the Enteric Nervous System to the Brain. 
Let us review some of the evidence in support of this hypothesis. Epidemiological studies have shown that involvement of the gastrointestinal tract is a very early non-motor symptom of PD. Constipation has been found to predate the appearance of motor symptoms by more than 10 years as documented in several reports ${ }^{22,23}$. The presence of early ASN immunostaining in the ENS has been found repeatedly in several studies analyzing surgical specimens both in PD-affected individuals and in controls $^{24}$. Post mortem studies in PD patients at different stages of the disease show the presence of ASN immunostaining along the vagal nerve and into the DMNV ${ }^{25}$. Alpha-synuclein is normally secreted by enteric neurons and functional studies show increased intestinal permeability, which correlates with sigmoid mucosa ASN staining and endotoxin exposure markers in early $\mathrm{PD}^{26,27}$. Furthermore, exposure of the ENS to environmental toxins (e.g. rotenone) reproduced ASN pathology and spreading in mice, providing support to the hypothesis of an environmental pathogen acting on the ENS as the initial trigger of ASN pathology ${ }^{28}$. Additional evidence highlighting the importance of the ENS in the pathogenesis of PD comes from the observation that, in mice overexpressing ASN, the gut microbiota are required for motor deficits, microglia activation, and ASN pathology ${ }^{29}$. Administration of antibiotics to these animals was found to improve both the pathology and motor deficits, while microbial recolonization promoted pathophysiological changes ${ }^{29}$. This evidence suggest that postnatal signaling between the gut and the brain is also capable of modulating disease expression.

In support of the hypothesis of the spreading of ASN along the vagal nerve, several experiments have used different approaches ${ }^{30,31}$ (accumulation of human ASN within medullary neurons was achieved via retrograde transport of adeno-associated viral vectors unilaterally injected into the vagus nerve in the rat neck; injection in the intestinal wall of a human PD brain lysate containing different forms of ASN [monomeric, oligomeric and fibrillary], and recombinant ASN in an in vivo animal model was transported via the vagal nerve and reached the DMNV in the brainstem in a time-dependent manner). These different approaches have provided evidence of the possibility of such a mechanism taking place in human disease ${ }^{30,31}$. Moreover, in more recent studies using rotenone locally applied to the enteric wall to trigger ASN pathology and progression in mice, surgical section of the autonomic nerves was able to stop progression ${ }^{28}$. Two recent epidemiological studies conducted in Sweden and Denmark found a reduced risk of the development of PD in individuals who underwent truncal vagotomy in comparison with those who were treated with selective or super-selective vagotomy for peptic ulcer disease, suggesting that sectioning of the vagus nerve theoretically would have prevented spreading of ASN pathology originated in the ENS ${ }^{32,33}$ (Figure 2).

Despite the mounting evidence in favor of this hypothesis, there are still some unanswered questions that cast doubt on its validity. Evidence of preceding constipation in PD patients may have been influenced by recall bias, and correlation in the aged individuals is less strong, while some individuals with positive immunostaining for ASN in the colonic mucosa had no constipation ${ }^{24}$; Braak's staging system is not applicable in all cases ${ }^{11}$; the presence of ASN immunostaining in the ENS has been found both in affected individuals and control cases alike ${ }^{24}$; and there is uncertainty as to the pathogenic relevance of enteric ASN immunostaining ${ }^{24}$. These caveats will hopefully fuel the development of more specific immunostaining techniques and prospective longitudinal studies to look, in more detail, at the progression of ASN pathology.

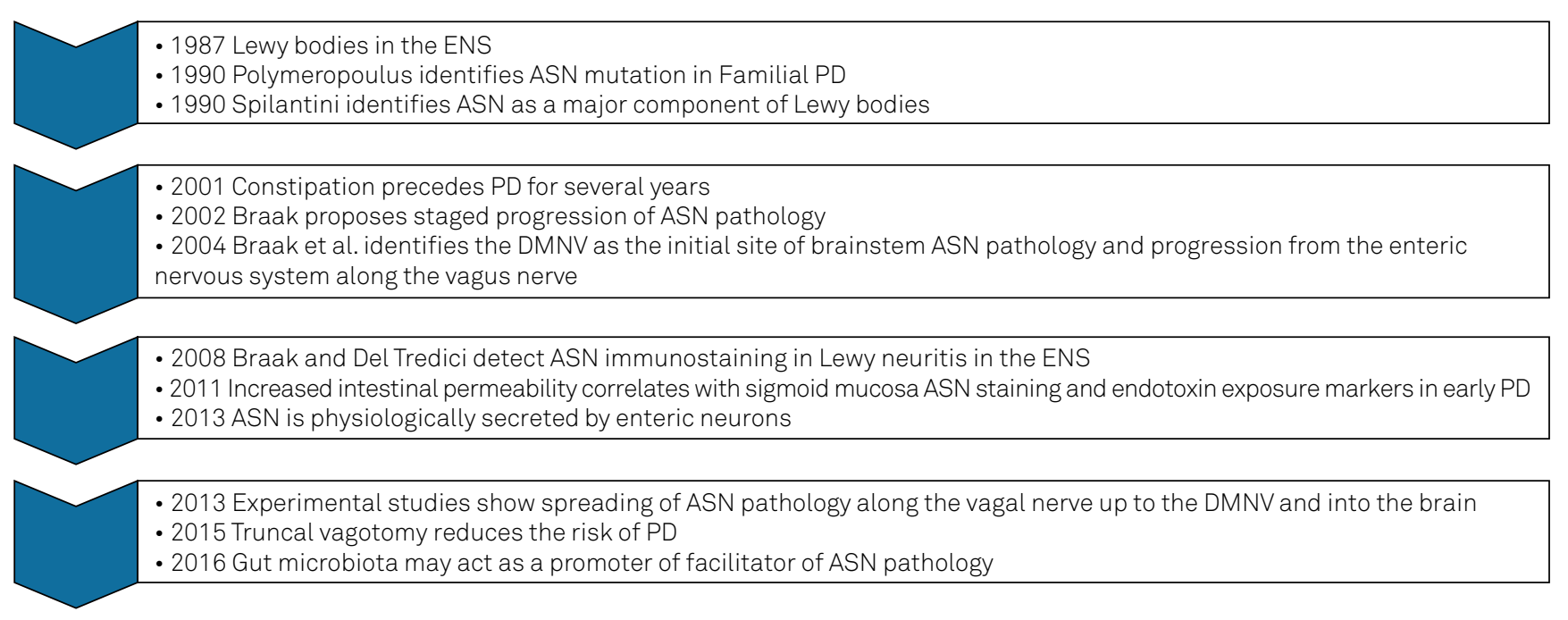

ASN: alpha-synuclein, DMNV: dorsal motor nucleus of the vagus, ENS: enteric nervous system.

Figure 2. Gut to brain transmission of alpha-synuclein pathology timeline. 
1. Polymeropoulos MH, Lavedan C, Leroy E, Ide SE, Dehejia A, Dutra A et al. Mutation in the alpha-synuclein gene identified in families with Parkinson's disease. Science. 1997 Jun;276(5321):2045-7. https://doi.org/10.1126/science.276.5321.2045

2. Spillantini MG, Schmidt ML, Lee VM, Trojanowski JQ, Jakes R, Goedert M. Alpha-synuclein in Lewy bodies. Nature. 1997 Aug;388(6645):839-40. https://doi.org/10.1038/42166

3. Klein C, Westenberger A. Genetics of Parkinson's disease. Cold Spring Harb Perspect Med. 2012 Jan;2(1):a008888. https://doi.org/10.1101/cshperspect.a008888 1

4. Spillantini MG, Goedert M. The alpha-synucleinopathies: parkinson's disease, dementia with Lewy bodies, and multiple system atrophy. Ann NY Acad Sci. 2000;920(1):16-27. https://doi.org/10.1111/j.1749-6632.2000.tb06900.x

5. Konno T, Ross OA, Puschmann A, Dickson DW, Wszolek ZK. Autosomal dominant Parkinson's disease caused by SNCA duplications. Parkinsonism Relat Disord. 2016 Jan;22 Suppl 1:S1-6. https://doi.org/10.1016/j.parkreldis.2015.09.007

6. Singleton AB, Farrer MJ, Bonifati V. The genetics of Parkinson's disease: progress and therapeutic implications. Mov Disord. 2013 Jan;28(1):14-23. https://doi.org/10.1002/mds.25249

7. Koprich JB, Kalia LV, Brotchie JM. Animal models of $\alpha$-synucleinopathy for Parkinson disease drug development. Nat Rev Neurosci. 2017 Sep;18(9):515-29. https://doi.org/10.1038/nrn.2017.75

8. Ingelsson M. Alpha-synuclein oligomers-neurotoxic molecules in Parkinson's disease and other lewy body disorders. Front Neurosci. 2016 Sep;10:408. https://doi.org/10.3389/fnins.2016.00408

9. Lim SY, Fox SH, Lang AE. Overview of the extranigral aspects of Parkinson disease. Arch Neurol. 2009 Feb;66(2):167-72. https://doi.org/10.1001/archneurol.2008.561

10. Braak H, Del Tredici K, Bratzke H, Hamm-Clement J, Sandmann-Keil D, Rüb U. Staging of the intracerebral inclusion body pathology associated with idiopathic Parkinson's disease (preclinical and clinical stages). J Neurol. 2002 Oct;249 Suppl 3:III/1-5. https://do.org/10.1007/s00415-002-1301-4 •

11. Jellinger KA. A critical evaluation of current staging of alpha-synuclein pathology in Lewy body disorders. Biochim Biophys Acta. 2009 Jul;1792(7):730-40. https://doi.org/10.1016/j.bbadis.2008.07.006

12. Rocha EM, Miranda B, Sanders LH. Alpha-synuclein: pathology, mitochondrial dysfunction and neuroinflammation in Parkinson's disease. Neurobiol Dis. 2017 Apr 8. pii: S0969-9961(17)30080-3. https://doi.org/10.1016/j.nbd.2017.04.004

13. Chu Y, Kordower JH. The prion hypothesis of Parkinson's disease. Curr Neurol Neurosci Rep. 2015 May;15(5):28. https://doi.org/10.1007/s11910-015-0549-x

14. Diógenes MJ, Dias RB, Rombo DM, Miranda HV, Maiolino F, Guerreiro P et al. Extracellular alpha-synuclein oligomers modulate synaptic transmission and impair LTP via NMDA-receptor activation. J Neurosci. 2012 Aug;32(34):11750-62. https://doi.org/10.1523/JNEUROSCI.0234-12.2012

15. Luk KC, Kehm VM, Zhang B, O'Brien P, Trojanowski $J Q$, Lee VM. Intracerebral inoculation of pathological $\alpha$-synuclein initiates a rapidly progressive neurodegenerative $\alpha$-synucleinopathy in mice.J Exp Med. 2012 May;209(5):975-86. https://doi.org/10.1084/jem.20112457

16. Luk KC, Kehm V, Carroll J, Zhang B, O'Brien P, Trojanowski JQ et al. Pathological $\alpha$-synuclein transmission initiates Parkinson-like neurodegeneration in nontransgenic mice. Science. 2012 Nov;338(6109):949-53. https://doi.org/10.1126/science.1227157

17. Shimozawa A, Ono M, Takahara D, Tarutani A, Imura S, Masuda-Suzukake M et al. Propagation of pathological $\alpha$-synuclein in marmoset brain. Acta Neuropathol Commun. 2017 Feb;5(1):12. https://doi.org/10.1186/s40478-017-0413-0
18. Recasens A, Dehay B, Bové J, Carballo-Carbajal I, Dovero S, Pérez-Villalba A et al. Lewy body extracts from Parkinson disease brains trigger $\alpha$-synuclein pathology and neurodegeneration in mice and monkeys. Ann Neurol. 2014 Mar;75(3):351-62. https://doi.org/10.1002/ana.24066

19. Lindström V, Fagerqvist T, Nordström E, Eriksson F, Lord A, Tucker $\mathrm{S}$ et al. Immunotherapy targeting $\alpha$-synuclein protofibrils reduced pathology in (Thy-1)-h[A30P] $\alpha$-synuclein mice. Neurobiol Dis. 2014 Sep;69:134-43. https://doi.org/10.1016/j.nbd.2014.05.009

20. Tran HT, Chung CH, Iba M, Zhang B, Trojanowski JQ, Luk KC et al. A-synuclein immunotherapy blocks uptake and templated propagation of misfolded $\alpha$-synuclein and neurodegeneration. Cell Reports. 2014 Jun;7(6):2054-65. https://doi.org/10.1016/j.celrep.2014.05.033

21. Houser MC, Tansey MG. The gut-brain axis: is intestinal inflammation a silent driver of Parkinson's disease pathogenesis? NPJ Parkinsons Dis. 2017 Jan;3(1):3. https://doi.org/10.1038/s41531-016-0002-0

22. Abbott RD, Petrovitch H, White LR, Masaki KH, Tanner CM, Curb JD et al. Frequency of bowel movements and the future risk of Parkinson's disease. Neurology. 2001 Aug;57(3):456-62. https://doi.org/10.1212/WNL.57.3.456

23. Savica R, Carlin JM, Grossardt BR, Bower JH, Ahlskog JE, Maraganore DM et al. Medical records documentation of constipation preceding Parkinson disease: a case-control study. Neurology. 2009 Nov;73(21):1752-8. https://doi.org/10.1212/WNL.0b013e3181c34af5 PMID:19933976

24. Ruffmann C, Parkkinen L. Gut feelings about $\alpha$-Synuclein in gastrointestinal biopsies: biomarker in the making? Mov Disord. 2016 Feb;31(2):193-202. https://doi.org/10.1002/mds.26480

25. Braak H, Ghebremedhin E, Rüb U, Bratzke H, Del Tredici K. Stages in the development of Parkinson's disease-related pathology. Cell Tissue Res. 2004 Oct;318(1):121-34. https://doi.org/10.1007/s00441-004-0956-9

26. Paillusson S, Clairembault T, Biraud M, Neunlist M, Derkinderen P. Activity-dependent secretion of alpha-synuclein by enteric neurons. J Neurochem. 2013 May;125(4):512-7. https://doi.org/10.1111/jnc.12131

27. Forsyth CB, Shannon KM, Kordower JH, Voigt RM, Shaikh M, Jaglin JA et al. Increased intestinal permeability correlates with sigmoid mucosa alpha-synuclein staining and endotoxin exposure markers in early Parkinson's disease. PLoS One. 2011;6(12):e28032. https://doi.org/10.1371/journal.pone.0028032

28. Pan-Montojo F, Schwarz M, Winkler C, Arnhold M, O'Sullivan GA, $\mathrm{Pal} \mathrm{A}$ et al. Environmental toxins trigger PD-like progression via increased alpha-synuclein release from enteric neurons in mice. Sci Rep. 2012;2(1):898. https://doi.org/10.1038/srep00898

29. Sampson TR, Debelius JW, Thron T, Janssen S, Shastri GG, I han ZE et al. Gut microbiota regulate motor deficits and neuroinflammation in a model of Parkinson's disease. Cell. 2016 Dec;167(6):1469-1480.e12. https://doi.org/10.1016/j.cell.2016.11.018

30. Ulusoy A, Musgrove RE, Rusconi R, Klinkenberg M, Helwig M, Schneider $A$ et al. Neuron-to-neuron $\alpha$-synuclein propagation in vivo is independent of neuronal injury. Acta Neuropathol Commun. 2015 Mar;3(1):13. https://doi.org/10.1186/s40478-015-0198-y

31. Holmqvist S, Chutna O, Bousset L, Aldrin-Kirk P, Li W, Björklund Tet al. Direct evidence of Parkinson pathology spread from the gastrointestinal tract to the brain in rats. Acta Neuropathol. 2014 Dec;128(6):805-20. https://doi.org/10.1007/s00401-014-1343-6

32. Svensson E, Horváth-Puhó E, Thomsen RW, Djurhuus JC, Pedersen L, Borghammer P et al. Vagotomy and subsequent risk of Parkinson's disease. Ann Neurol. 2015 Oct;78(4):522-9. https://doi.org/10.1002/ana.24448

33. Liu B, Fang F, Pedersen NL, Tillander A, Ludvigsson JF, Ekbom A et al. Vagotomy and Parkinson disease: aSwedish register-based matchedcohort study. Neurology. 2017 May;88(21):1996-2002. https://doi.org/10.1212/WNL.00000000000003961 